\title{
DESIGN FOR ENVIRONMENT AND FORM FINDINGS THROUGH DIGITAL FABRICATION
}

\author{
Stephanus Evert Indrawan \\ Interior Architecture Department, Ciputra University, UC Town-Citraland Surabaya \\ Email: sindrawan@ciputra.ac.id
}

\begin{abstract}
The material processing for the needs of architectural, interior and furniture products were done manually all this time. Woodworking machinery (one of them is CNC) and CAD-based software were only been maximized as supporting tools to increase the speed of working process, resulting the outcome products were limited to manual working outcome only. This recent research on form processing aims to maximize the optimal use of material in the contexts of achieving structural ability and complex form. Plywood material becomes the focus in this research, due to its most frequent use in architecture, interior, and product design. With its texture that resembles the characteristics of original wood and its sheet-shaped form, this plywood material is easy to process and environmentally friendly. Digital fabrication enables the designer in design process and simulation through software to shorten the prototyping process which usually took loads of materials, thus can reduce the materials waste. The project that presented is an example of design production with physical examples.
\end{abstract}

Keywords: Digital fabrication; design; architecture; interior; products.

\section{INTRODUCTION}

Digital Design and Digital Fabrication is set of activities in processing geometry models and data through intensive use of computer. Digital fabrication is a manufacturing process where the use of machine is controlled by computer (Computer Numeric Controller). Besides discussing the application of $\mathrm{CNC}$ on the models, this research also reviews in general the design process and product through Design for Environment rubric. The followings are general explanation on the Digital Fabrication and Design for Environment.

Initially, digital fabrication laboratory was known as Rapid Prototyping Labs. At the end of 1990s, this kind of laboratory was mostly found in reputable architecture schools. Obviously, there were things behind the drastic change of this laboratory. In 1923 and in 1928, László Moholy-Nagy delivered a very important concept in Bauhaus education, namely the introduction to art, science and technology in the learning process. László Moholy-Nagy (1938) was one of the Bauhaus professors of Hungarian nationality who was very enthusiastic about industrial processes that affect material quality. His notion is referenced in a book entitled "Von Material zu Architektur (1992)" (translated into English under the title "The New Vision" (1938). The method he states is quoted as follows:

Teachers and students in close collaboration are bound to find new ways of handling materials... materials through actual experience of its properties, its possibilities in plastic handling, in tectonic creation, in work with tools and machines such as is never attained through book knowledge in the usual school exercises and the traditional courses of instruction (1938:23).

After World War Two, or after the era of Bauhaus, many professional vocational schools (such as Bauhaus itself) merged with universities, resulting in the presence of science in Simon learning content:

It is ironic that in this century the natural sciences almost drove the sciences of artificial from professional school curricula, a development that peaked about two or three decades after Second World War (1998:111)

Later on, the architecture learning began to develop with the content of science, while the concept of traditional learning was left behind. This triggered the emergence of Design Methods Movement in the 1960 where the complexity of spatial program increased and architecture evolved towards the realm of operational research, artificial intelligence and computer technology. The aims of these changes are: (1) designing better by understanding design process; (2) involving people outside the discipline to cooperate together; (3) using computer to finish repetitive parts of a design process (Gregory, 1971).

In a traditional architecture process, the design process is not run scientifically and systematically. The design process is generally explorative is explorative and through a process of trial and error. The 
nature of new educational architecture is the simulation of physical concept in an architectural application, for example, acoustics, lighting, and statics. The name "Laboratory Design" is then increasingly being used since the emergence of this concept, as supported by Rivka Oxman and Robert Oxman (2010):

Fabrication labs in education, which were rare even just a few years ago, are today a common place"(2010:23)

Digital Fabrication is a product of collaboration between Architecture with Mechanical Engineering, supported by the knowledge of Design for Environment that will increase their own value. Forming a metal material for shape of car body can be reasonable but constructing a complex geometry in an architectural design can be less clear. The shape should be managed into simpler parts. According to Lars Spuybroek (2016), "panelization is hugely important issue", since traditional CAD software does not cover this topic.This study also discusses the general principles of Design for Environment (abbreviated as DfE). Crow (2002) stated three major elements in order to design for the environment: environmental manufacturing, design for environmental packaging, and design for disposal and recyclability. In particular, integrated $\mathrm{CAD} / \mathrm{CAM}$ has an impact to reduce paper used for drawing

Table 1. Rubric to Categorize DfE Principles based on Product Lifecycle

\begin{tabular}{|c|c|c|}
\hline Product Lifecycle & Definition & Example \\
\hline Raw Material Extraction & $\begin{array}{l}\text { The DfE Principle impacts the process of extracting } \\
\text { raw including material selection, material } \\
\text { identification, and the process of extracting raw } \\
\text { materials from the environment. }\end{array}$ & $\begin{array}{l}\text { "Uses locally available materials and } \\
\text { resources" }\end{array}$ \\
\hline Material Processing & $\begin{array}{l}\text { The DfE Principle impacts the processes that turn raw } \\
\text { materials into finished materials and products. }\end{array}$ & "Minimizes material variety" \\
\hline Component Manufacturing & $\begin{array}{l}\text { The DfE Principle impacts the manufacture of the } \\
\text { individual components of a product. }\end{array}$ & "Reduces product dimensions" \\
\hline Assembly & $\begin{array}{l}\text { The DfE Principle impacts the final assembly of both } \\
\text { individual components produced on-site and } \\
\text { components manufactured by suppliers }\end{array}$ & $\begin{array}{l}\text { "Contains multifunctional parts" } \\
\text { "Minimizes the use of fasteners" }\end{array}$ \\
\hline Packaging & $\begin{array}{l}\text { The DfE Principle impacts life cycle considerations of } \\
\text { a product's packaging. }\end{array}$ & $\begin{array}{l}\text { "Design packaging for refilling rather } \\
\text { than replacement" }\end{array}$ \\
\hline Transportation \&Distribution & $\begin{array}{l}\text { The DIE Principle impacts the transportation and } \\
\text { distribution of goods, from final assembly to the } \\
\text { customer. }\end{array}$ & "Use an efficient transport system" \\
\hline Installation \& Use & $\begin{array}{l}\text { The DIE Principle impacts the use phase of a product's } \\
\text { life cycle, specifically a product's interactions with the } \\
\text { user. }\end{array}$ & $\begin{array}{l}\text { "Incorporates power down features for } \\
\text { different subsystems in the product } \\
\text { when they are not in use" }\end{array}$ \\
\hline Upgrading \&Maintenance & $\begin{array}{l}\text { The DfE Principle impacts services that address the } \\
\text { shortcomings of a product experienced during use. }\end{array}$ & $\begin{array}{l}\text { "Contains an "up cycling passport" } \\
\text { that encodes information about } \\
\text { material ingredients" }\end{array}$ \\
\hline Staying Alive & $\begin{array}{l}\text { The DfE Principle impacts all product lifecycle phases, } \\
\text { with the goal increasing the amount of time it spends in } \\
\text { the use phase, delaying the end of life of a product }\end{array}$ & $\begin{array}{l}\text { "Design products to be expandable, } \\
\text { allowing other devices to be added or } \\
\text { attached as they come become } \\
\text { available or change" }\end{array}$ \\
\hline End of Life & $\begin{array}{l}\text { The DfE Principle impacts what happens to a product } \\
\text { after it can no longer be made use of in its current } \\
\text { condition; includes recycling \& biodegradability. }\end{array}$ & $\begin{array}{l}\text { "Develops uses for waste materials } \\
\text { and creates products that can be } \\
\text { produced from it" }\end{array}$ \\
\hline Transmaterialization & $\begin{array}{l}\text { The DIE Principle expands the nature of the product, } \\
\text { transforming product models into service models. }\end{array}$ & $\begin{array}{l}\text { "Transform product models into } \\
\text { service models that can more } \\
\text { efficiently use resources and thus } \\
\text { reduce impacts" }\end{array}$ \\
\hline Transparency & $\begin{array}{l}\text { The DfE Principle relates to collection of information } \\
\text { throughout the whole life cycle of the product, and } \\
\text { open communication of that information. }\end{array}$ & $\begin{array}{l}\text { "Report on and communicate } \\
\text { sustainability investments and } \\
\text { achievements" }\end{array}$ \\
\hline Pervasive & $\begin{array}{l}\text { The DIE Principle applies to all phases of the product } \\
\text { lifecycle. }\end{array}$ & $\begin{array}{l}\text { "Acknowledges the values and } \\
\text { purposes that motivate design" }\end{array}$ \\
\hline Business Practices & $\begin{array}{l}\text { The DfE Principle concerns business practices; it is } \\
\text { independent of the product's lifecycle or production. }\end{array}$ & $\begin{array}{l}\text { "Incorporate sustainability into the } \\
\text { overall business strategy and policy of } \\
\text { the company" }\end{array}$ \\
\hline
\end{tabular}

(Source: Oehlberg, 2012) 
documentation by allowing model geometry driving component production. Telenko (2009) states four criteria for DfE principles, namely design oriented, actionable, general and positive imperative. This recent study limits its discussion on the product lifecycle influencing the DfE.

\section{Design Approach}

Results of this recent study is going to be applied in Pavilion form. Pavilion is a model of study to represent the value of form specifically, thus the value of function in this study was excluded.

\begin{tabular}{|c|c|c|c|c|c|c|}
\hline $\begin{array}{l}\text { Spatial } \\
\text { Concept }\end{array}$ & $\Rightarrow$ & $\begin{array}{l}\text { Geometrical } \\
\text { Constraint }\end{array}$ & $\Rightarrow$ & $\begin{array}{l}\text { Material } \\
\text { Contstraint }\end{array}$ & $\Rightarrow$ & Solution \\
\hline
\end{tabular}

Fig. 1. Top Down Scheme (Gillkvist, 2016)

\begin{tabular}{|l|l|l|l|l|l|l|l|}
\hline $\begin{array}{l}\text { Spatial } \\
\text { Concept }\end{array}$ & $\begin{array}{l}\text { Geometrical } \\
\text { Constraint } \\
\text { Contstraint }\end{array}$ & Solution \\
\hline
\end{tabular}

Fig. 2. Bottom Up Scheme (Gillkvist, 2016)

The design method used consisted of two: top down and bottom up. Top Down is an approach that uses regular steps or decomposition. This stage begins by looking at the whole big picture of the project which is then broken down into several sub-systems. The objective of this stage is to clarify the vision and missions of a project. However, the design process through this stage tends to end irregularly. Bottom up is a system in which all approaches are combined together to form the main system. Bottom up provides flexibility in the design but the results can be so complex it can be very difficult to understand. Considering the limitations of each system, the combination of top down and bottom up is then required.

In a design process, there are three levels of approach that can be used. They are Spatial, Structures or Geometric, and Material. In this scheme, the approach with top down and bottom up systems was used to actualize the design.

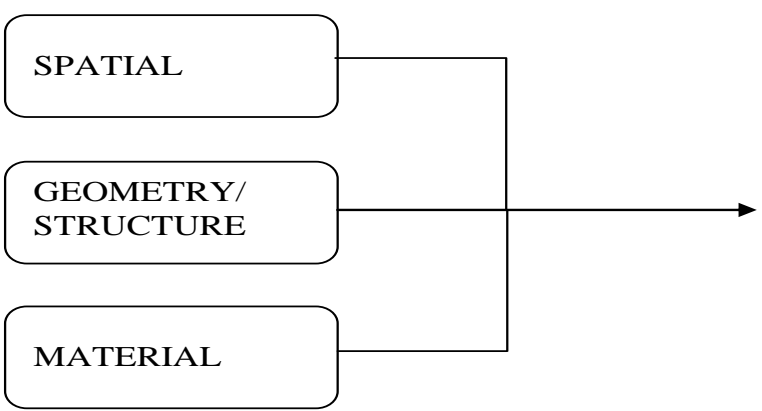

Fig. 3. Levels of initial design Scheme (Gillkvist, 2016)

\section{SPATIAL DESIGN}

The Pavilion was an experimental project that being built for exhibition booth. This Pavilion was designed and built by Laboratory of Whatever (WLAB) Architects, Lecturer and Students from Interior Architecture Department of Ciputra University. Function is not a major constraint or can be ignored. However, the pavilion in a whole will form a space blanket, with its supporting structure and roof that covers. The initial idea of this pavilion's form was adopting the shape of a mushroom.

Based on Figure 4 and figure 5, there are three important structures of a mushroom: 1) the section of gills or thin layers under the cap of a mushroom, 2) the shape of mushroom, and 3) the stem of a mushroom as its supporting structure.

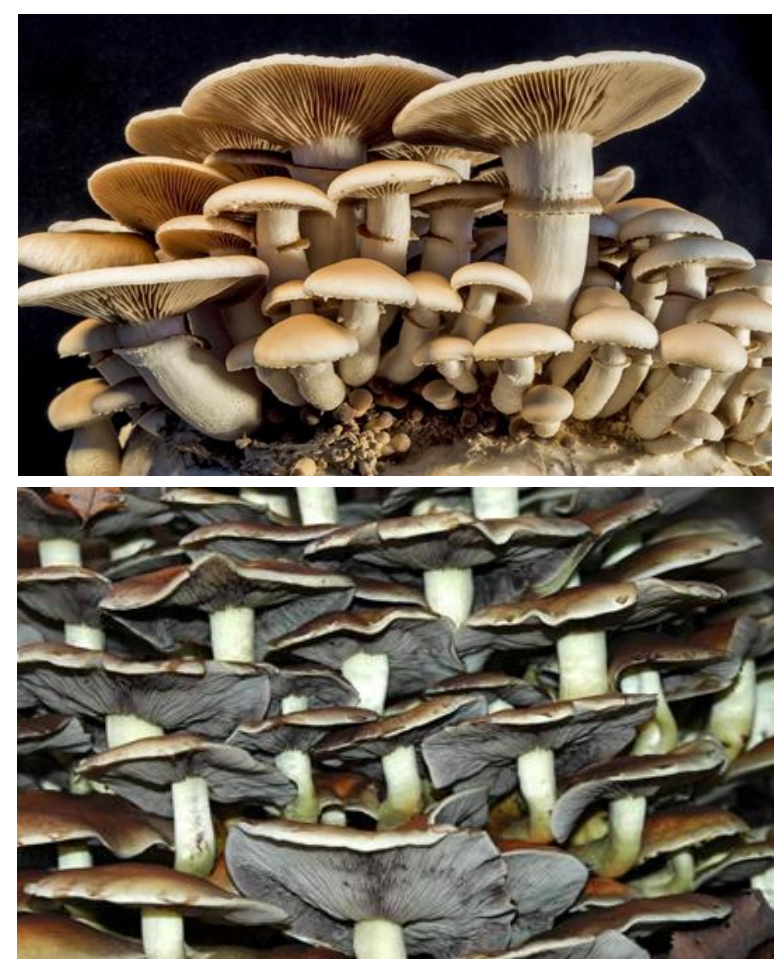

Fig. 4. Shape of Mushroom as Reference Idea for Design (Google Image)

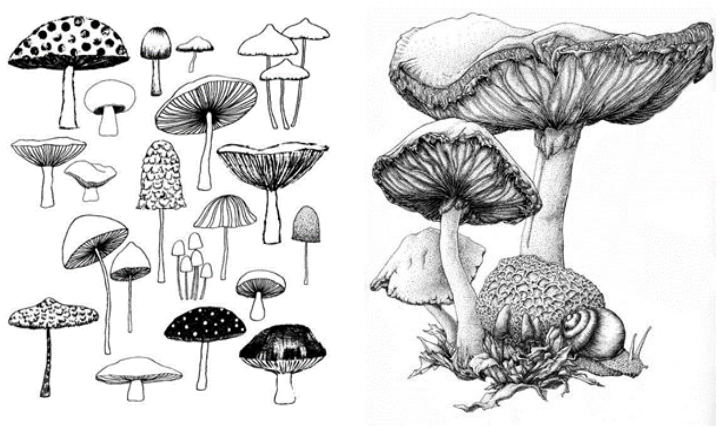

Fig. 5. Mushroom (Google Image) 


\section{Structure}
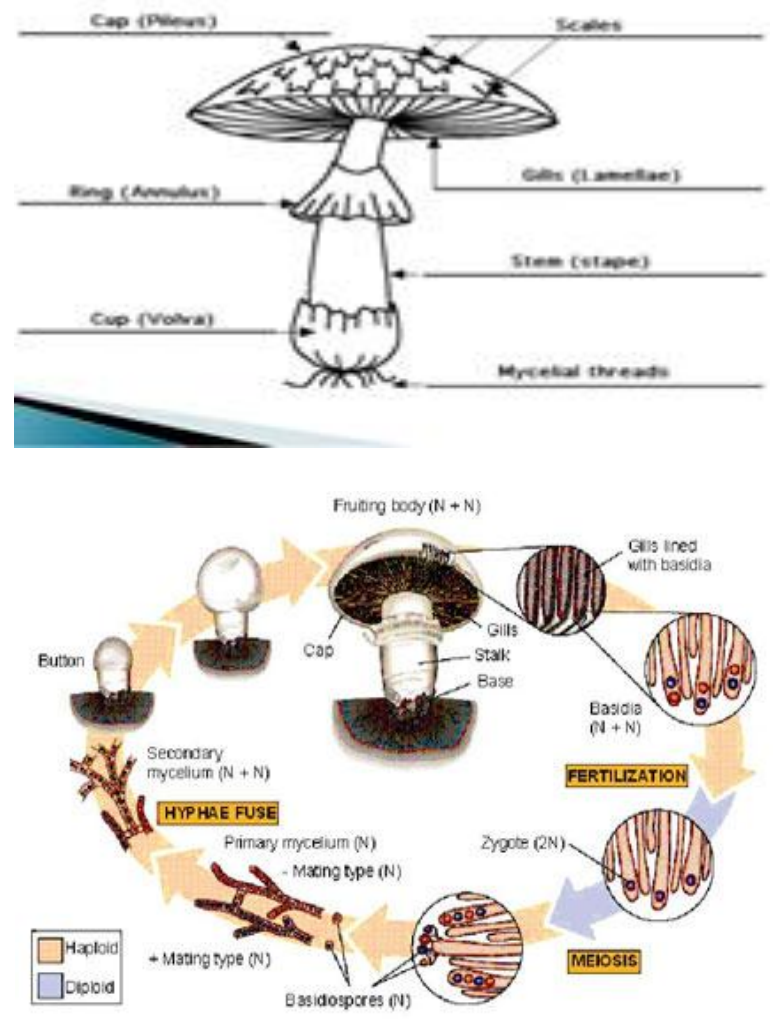

Fig. 6. Identification of Mushroom (Google Image)

The mushroom shape has been well known as idea reference in the world of architecture.
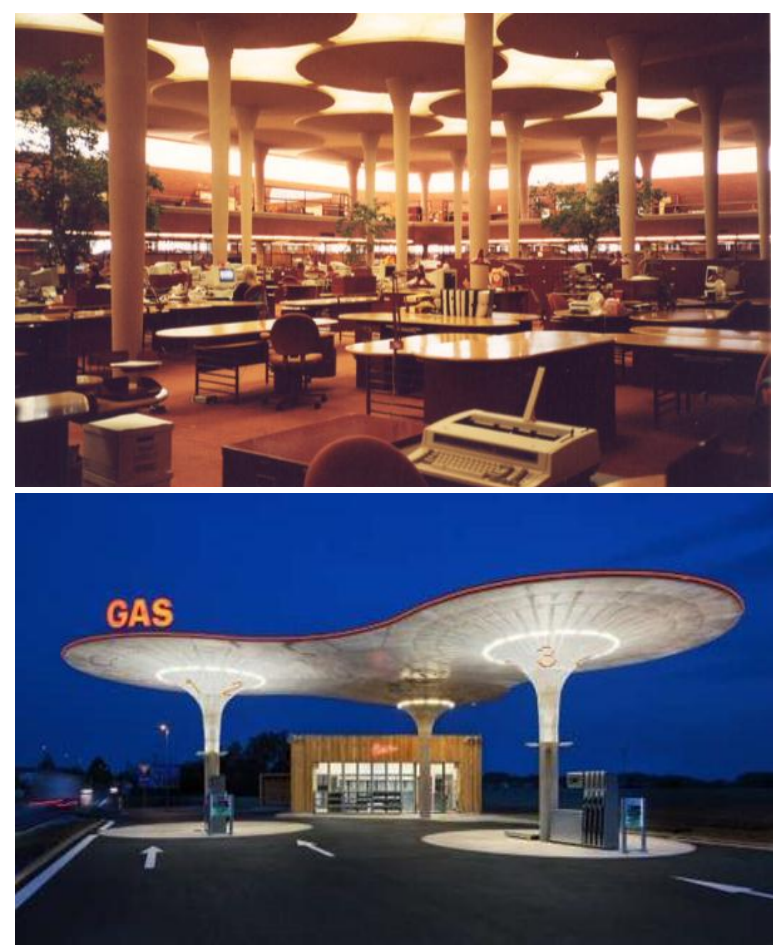

Fig. 7. Building that Adapts to Mushroom Shape by Frank Lloyd Wright and Atelier SAD (Google Image)

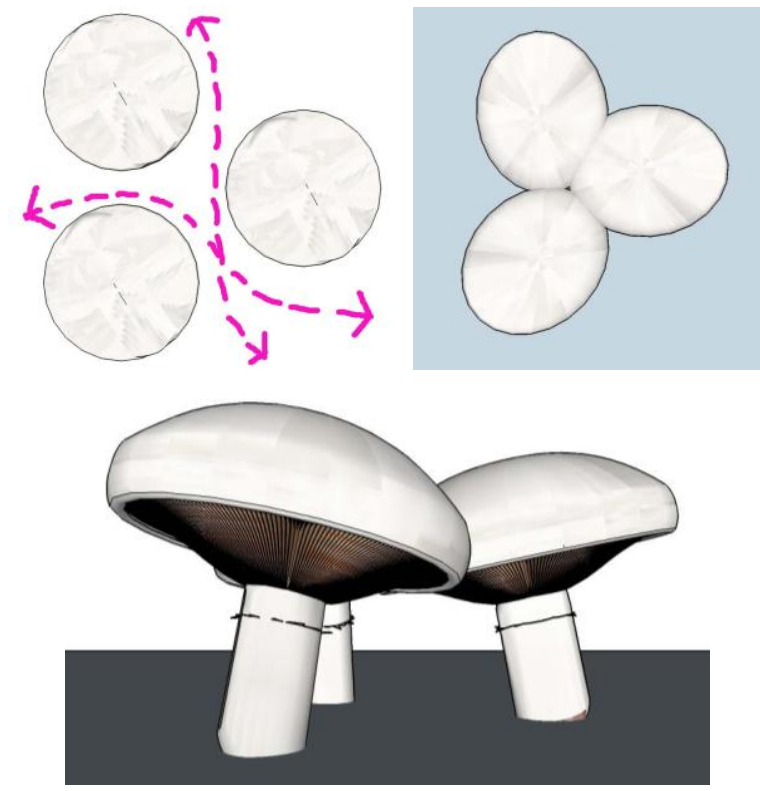

Fig. 8. Circulation Study and Basic Form of Pavilion

Figure 8 graphically explains the pattern of circulation of visitors that can go through the pavilion to experience the inside and outside spaces of the formed building. The composition of this formation consisted of three intersections as adapted from the mushroom shape, thus resulting this pavilion is structurally stable and has asymmetrically composition to avoid monotonous impression. This pavilion also aims to create organic object.

\section{Geometry/Structure}

This study explores the possibilities of processing the form from the side of geometry and of material. Lisa Iwamoto categorizes the formation exploration through Digital Fabrication methods in five categories, namely (1) sectioning, (2) tessellating, (3) folding, (4) contouring, and (5) forming. This recent study limits its discussion on the category of sectioning method.

Orthographic Projections, or mostly known as pictures and pieces of plan, is a tool of communication for architects. Digital Fabrication uses sectioning method to decompose complex formation into the computer. This method is not intended to create surface of an object, but to maximize the profile of each cut object, where all using Rhinoceros software, the interval between sections can be easily arranged. Serialized Section can be used as either surfaceshaping elements or structure elements. In the world of Industry, this process has actually been commonly used for a long time, especially in the manufacture of aircraft and ships. In manufacturing ships, serialized section is an arrangement of structural ribs. 


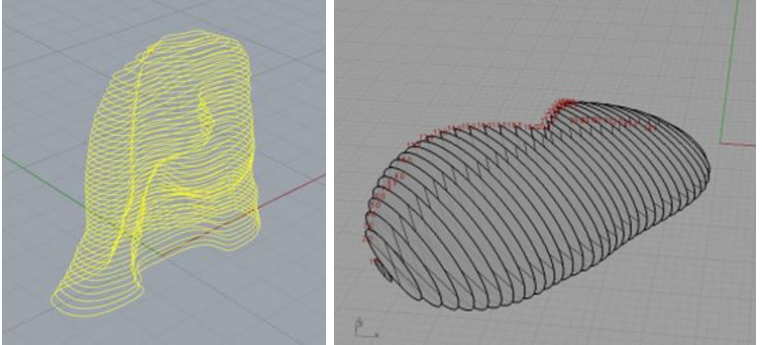

Fig. 9. Contouring using Rhinoceros Software (Iwamoto, 2009)

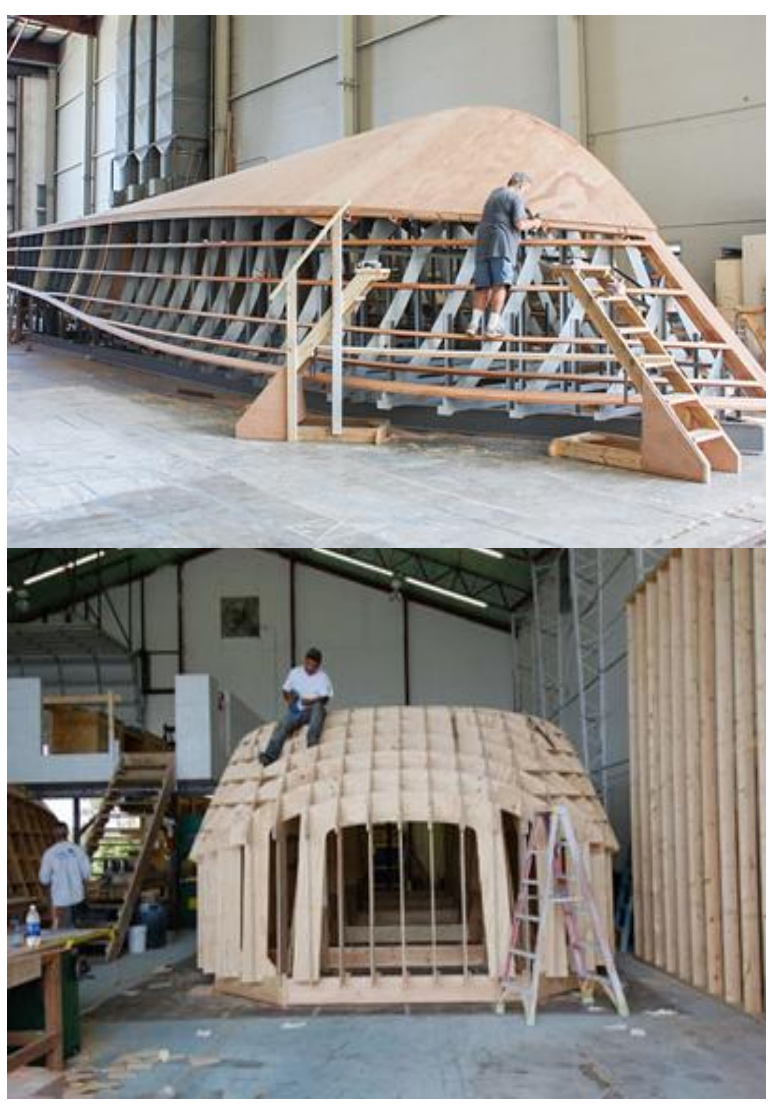

Fig. 10. Serialized Ribs for Structure of a Ship (Iwamoto, 2009)

Even during Le Corbusier's era, this method was applied in the process of roofs construction. The component of it consist of concrete ribs that connected by crossbeams. In the book of "Ronchamp", Le Corbusier name this type of construction as "seven strong, flat beams, 17 centimeter thick, all different".

Later, this sectioning is developed into waffleshaped system, a combination of two axis system structures. This structure resembles the shape of ice trays. Jakob and MacFarlane (2001) use waffle construction as the main formation of the design for project Loewy Bookshop. This formation functions very well as a bookshelf and interior element. Besides its interesting structure, this formation can also appear in modular shape and come in various scales.
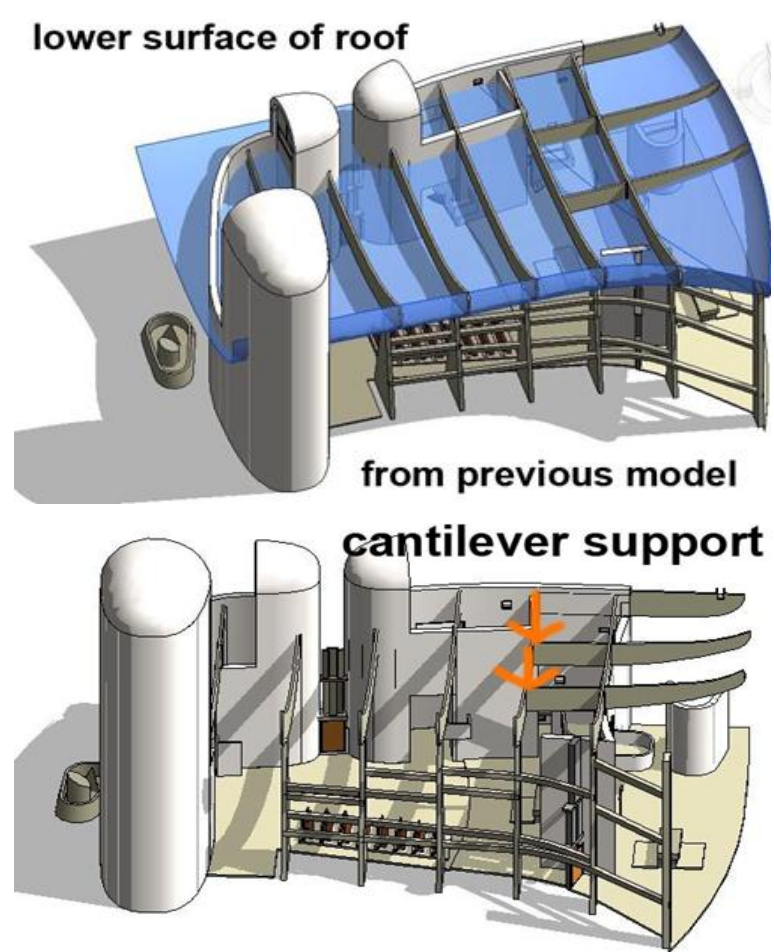

Fig. 11. Construction of Ronchamp's Roof
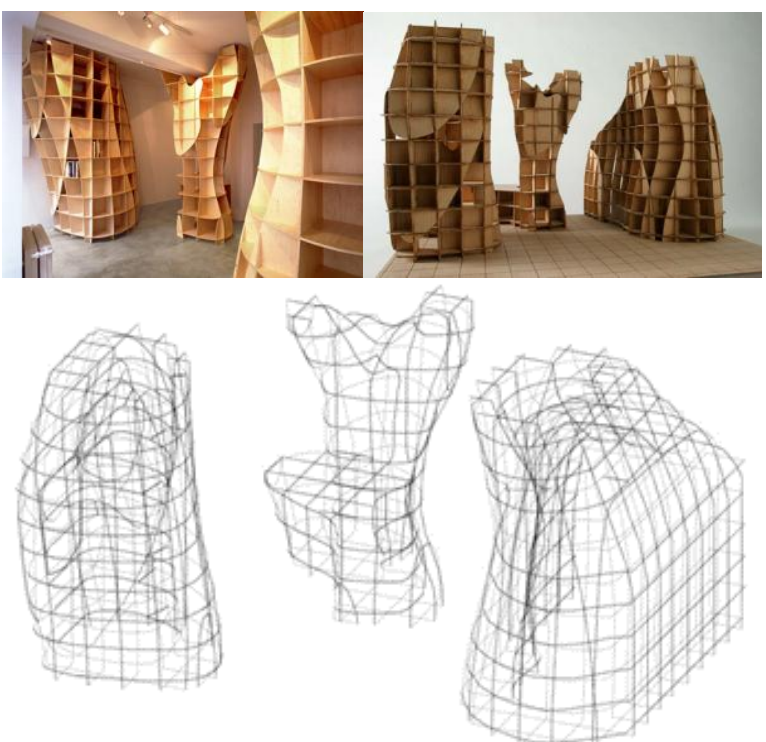

Fig. 12. Interior Element by Jakob and MacFarlane (Iwamoto, 2009)

Alvaro Siza and Eduardo Souto de Mouro (2005), in collaboration with structure consultant Cecil Balmond, created an installation project for the Serpentine Gallery with a wide expanse of waffle structure which is also referred to in other name as Grid Shell. In this project, the planar structure functions as a beam can be connected to un-standard connection made by five-axis CNC machine. Every 427 pieces of wood in this installation has a unique profile as the mapping results of thirty-six point resulted from computer script processing. 

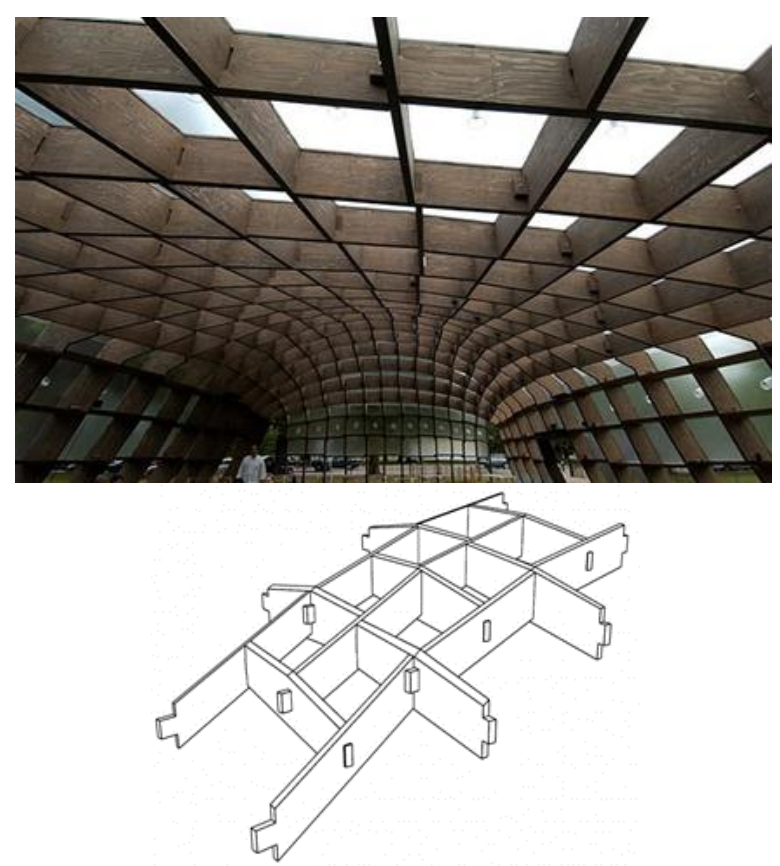

Fig. 13. Serpentine Gallery by Alvaro Siza and Souto de Mouro (Iwamoto, 2009)

Based on the understanding and references regarding the sectioning method, the researcher with WLAB (Laboratory of Whatever) attempt to develop the design of pavilion using Rhinoceros software supported by plug-ins grasshopper.

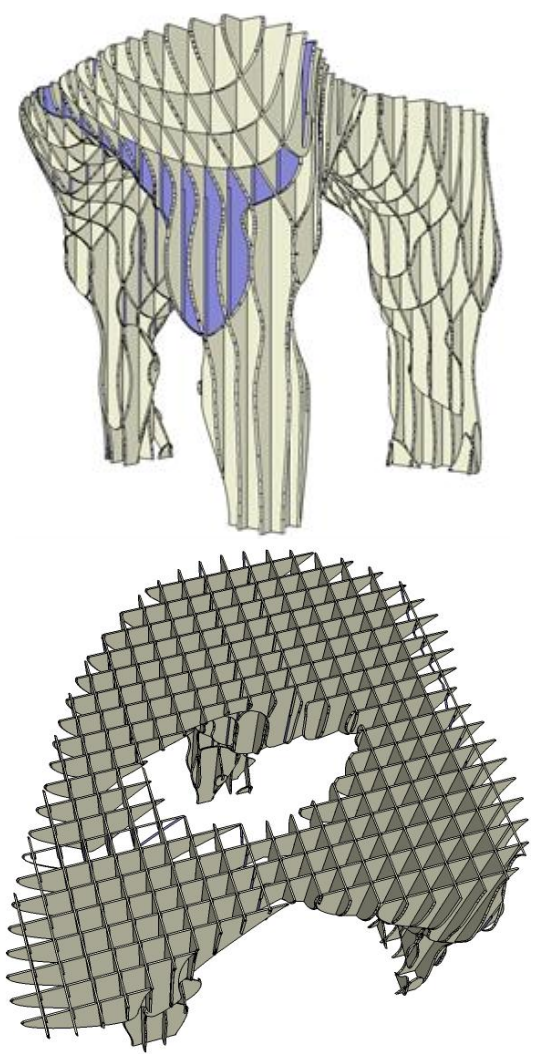

Fig. 14. Perspective and Top View of the Pavilion

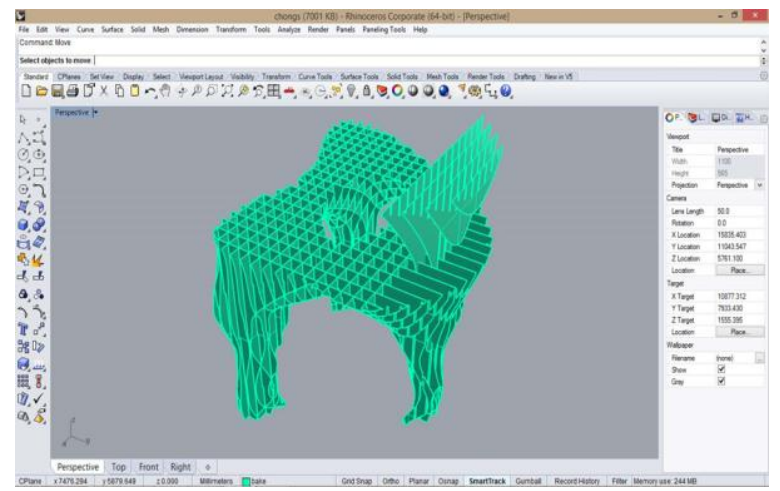

Fig. 15. Design with Sectioning Method

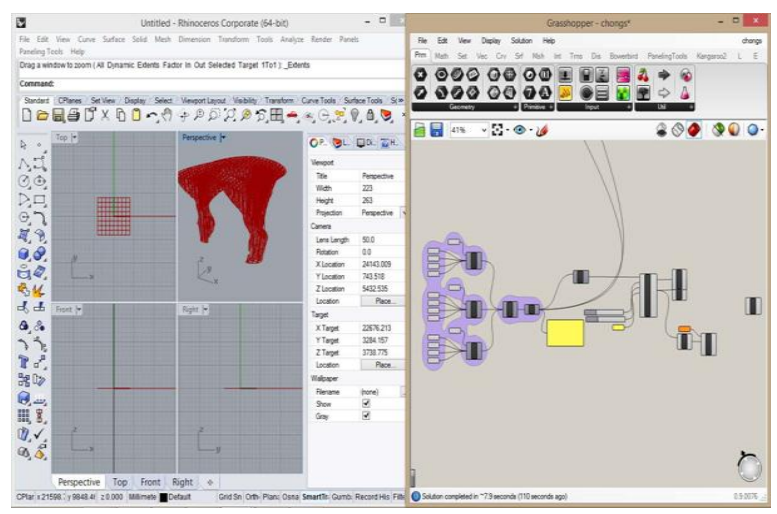

Fig. 16. Design with Rhino and Grasshopper Software

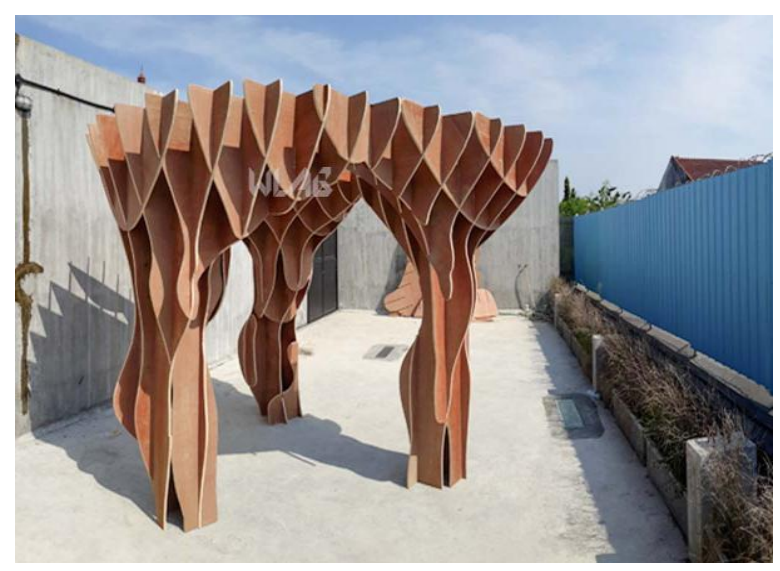

Fig. 17. Realization of Pavilion using Plywood Material plywood

\section{Material}

Material with planar formation is a commonly produced material of formation. Thus, plywood is used as primary material in the making of this Pavilion. The sectioning method and material process through CNC machine and computer help the designer resolves the limitations of size (one sheet of plywood (the average size of one Plywood sheet is $1.20 \times 2.40 \mathrm{~m})$. Table 2 contents the assessment results by using the rubric of DfE. 
Table 2. Research Result based on Rubric to Categorize DfE Principles

\begin{tabular}{|c|c|c|}
\hline Product Lifecycle & Definition & Application \\
\hline Raw Material Extraction & $\begin{array}{l}\text { The DfE Principle impacts the process of extracting raw } \\
\text { materials, including material selection, material } \\
\text { identification, and the process of extracting raw materials } \\
\text { from the environment. }\end{array}$ & $\begin{array}{l}\text { Plywood material is a local material with } \\
\text { various qualities to meet various needs. }\end{array}$ \\
\hline Material Processing & $\begin{array}{l}\text { The DfE Principle impacts the processes that turn raw } \\
\text { materials into finished materials and products. }\end{array}$ & $\begin{array}{l}\text { Sectioning and Diagrid methods allow } \\
\text { the design to rely on joint design and } \\
\text { reduce the use of binder }\end{array}$ \\
\hline Component & The DfE Principle impacts the manufacture of the & Digital fabrication can overcome the \\
\hline Manufacturing & individual components of a product. & limitations of material module \\
\hline Assembly & $\begin{array}{l}\text { The DfE Principle impacts the final assembly of both } \\
\text { individual components produced on-site and components } \\
\text { manufactured by suppliers. }\end{array}$ & $\begin{array}{l}\text { Assembling process becomes faster, } \\
\text { thereby reducing energy use }\end{array}$ \\
\hline Packaging & $\begin{array}{l}\text { The DfE Principle impacts life cycle considerations of a } \\
\text { product's packaging. }\end{array}$ & $\begin{array}{l}\text { Flatpack method can reduce the volume } \\
\text { of goodssignificantly }\end{array}$ \\
\hline Transportation & The DfE Principle impacts the transportation and & Product of digital precision is more \\
\hline \&Distribution & distribution of goods, from final assembly to the customer. & $\begin{array}{l}\text { precise, allowing the users make ease of } \\
\text { the assembling process }\end{array}$ \\
\hline Installation \& Use & $\begin{array}{l}\text { The DfE Principle impacts the use phase of a product's life } \\
\text { cycle, specifically a product's interactions with the user. }\end{array}$ & Depending on the materials used \\
\hline Upgrading & The DfE Principle impacts services that address the & This section method is structural in \\
\hline \&Maintenance & shortcomings of a product experienced during use. & $\begin{array}{l}\text { nature, so other complementary elements } \\
\text { can be added to it }\end{array}$ \\
\hline Staying Alive & $\begin{array}{l}\text { The DfE Principle impacts all product lifecycle phases, } \\
\text { with the goal increasing the amount of time it spends in } \\
\text { the use phase, delaying the end of life of a product. }\end{array}$ & $\begin{array}{l}\text { This section method is structural in } \\
\text { nature, so other complementary elements } \\
\text { can be added to it }\end{array}$ \\
\hline End of Life & $\begin{array}{l}\text { The DfE Principle impacts what happens to a product } \\
\text { after it can no longer be made use of in its current } \\
\text { condition; includes recycling \& biodegradability. }\end{array}$ & $\begin{array}{l}\text { The neatness working result of } \mathrm{CNC} \\
\text { machine allows to use materials in any } \\
\text { size }\end{array}$ \\
\hline Transmaterialization & $\begin{array}{l}\text { The DfE Principle relates to collection of information } \\
\text { throughout the whole life cycle of the product, and open } \\
\text { communication of that information. }\end{array}$ & $\begin{array}{l}\text { Designers are directly involved in the } \\
\text { process }\end{array}$ \\
\hline Pervasive & $\begin{array}{l}\text { The DfE Principle applies to all phases of the product } \\
\text { lifecycle }\end{array}$ & $\begin{array}{l}\text { Digital technology makes it possible to } \\
\text { make the design becomes more specific } \\
\text { and allows the designer to identify } \\
\text { material from a different angle }\end{array}$ \\
\hline Business Practices & $\begin{array}{l}\text { The DfE Principle concerns business practices; it is } \\
\text { independent of the product's lifecycle or production. }\end{array}$ & $\begin{array}{l}\text { Progress of Green Technology can } \\
\text { support the production of digital design }\end{array}$ \\
\hline
\end{tabular}

\section{RESULTS AND DISCUSSION}

Plywood as a main constructions material has a different potential through digital fabrications approach. Digital Fabrication gives a possibilities to Digital Fabrication Laboratory has become part of the study design, therefore interdisciplinary knowledge from other disciplines are now required. Digital fabrication, as well as orthographic projection, is a tool to communicate ideas. Though the method of material processing through the approach of digital fabrication requires the designers to have more involvement in the process, the working process is more simplified. In the making process of this pavilion, all participants involved in the project are students and instructor without any professional construction workers. Digital fabrication also allows the designer to realize complex formation with contemporary premise. Considering the novelty use of digital fabrication in Indonesia, the same vision of other related scientific fields is very much required for its implementation.

\section{CONCLUSSION}

The use of CNC machine and other supporting manufacturing equipment in the world of digital fabrication allows the designer to create a more complex shape, and to shorten time in the making of conventional formation as well. Its design sustainable factor in digital fabrication must be viewed from different perspective, for example, through Lifecycle 
Analysis in the form of DfE rubric. This is to consider the most intensive use of machines in the design which greatly influences the total energy used.

\section{REFERENCES}

Balmond, Cecil. 2006. Serpentine Gallery Pavilion 2005: Alvaro Siza and Eduardo Souto De Moura. ed. Hans-Ulrich Obrist. Trolley Books; illustrated edition edition (March 1, 2006), pp. 75-80

Iwamoto, L. (2009). Architectural and Material Techniques, Princeton Architectural Press., New York, pp. 10-14.

Oehlberg, L., Bayley, C., Hartman, C. \& Agogino, A. (2012). Leveraging Technology for a Sustainable World, eScholarship, California, pp. 221224.

Celani, G. (2012). Digital Fabrications Laboratories: Pedagogy and Impacts on Architectural Education. Journal Nexus Netw, 14, pp. 469-482.

Crow, K. 2002. "Design for The Environment.", pp. 45-50

Gillkvist, O., Henriksson, V. \& Pulsen, E. (2016). Design and Fabrication of Full scale Exhibition Structure in Plywood, Chalmers University. pp. 15-20.
Images Publishing Group. 2006. Jakob + Mac Farlane: NEO Architecture. pp. 38

Moholy-Nagy, László. 1938. The New Vision: Fundamentals of Bauhaus Design, Painting, Sculpture, and Architecture. Dover Publications (January 18, 2005), pp. 23.

Spuybroek, Lars. 2016. The Sympathy of Things: Ruskin and the Ecology of Design $2^{\text {nd }}$ Edition.

Oxman, Rivka. 2010. "The New Structuralism: Design, Engineering and Architecture Technologies AD Architectural Design.” AD Architectural Design, 4: 80.

Sass, L. (2006). Synthesis of design production with Integrated Digital Fabrication, Automation in Construction, 16, pp. 298-310.

Telenko, Cassandra, Seepersad, C.C. \& Webber, M. E. (2009). "A Method for Developing Design for Environment Guidlines for Future Product Design." Proceedings of the ASME 2009 International Design Engineering Technical Conferences \& Computers \& Information in Engineering Conference IDETS/CIE 2009: 12.

Odum, H.T. \& Odum, B. Concepts and Methods of ecological Engineering. Ecollogical Engineering. 20, pp. 339-361.

Pottmann, H., Schiftner, A. \& Wallner, J. (2008). Geometry of Architectural Freeform Structures. International Mathematic Nachrichten. 209, pp. 15-28. 